\title{
The managerial power of compensation: a contingency model
}

\author{
Andrew J. Templer \\ School of Business Leadership, University of South Africa
}

In this final article in a series of three on power, an attempt is made to integrate the organization compensation system into the models of managerial power presented earlier. It is argued that compensation is an area in which management has a considerable opportunity for exercising power. This opportunity is the result of the extreme importance of compensation to employees and the relative ease with which it can be manipulated by management. It is considered that the model presented in this article provides some of the basis for understanding and utilizing the power of compensation.

S. Afr. J. Bus. Mgmt. 1981, 12: $9-13$

In hierdie finale artikel in 'n reeks van drie oor mag word ' $n$ poging aangewend om die organisasie-vergoedingsteisel binne die modelle van bestuursmag voorheen aangebied, te in tegreer. Dit word aangevoer dat ' $n$ gebied is waarin bestuur 'n aansienlike geleentheid het om mag uit te oefen. Hierdie geleentheid is die resultaat van die uiterste belang van vergoeding vir werknemers en die relatiewe gemak waarmee dit deur bestuur hanteer kan word. Die model wat in hierdie artikel aangebied word, dra by tot die basis vir die begrip en aanwending van die mag van vergoeding.

S.Afr. Tydskr. Bedryfsl. 1981, 12: 9-13
In two earlier articles ${ }^{1,2}$ the author presented a general model of managerial power which included a focus on both the macro and the micro levels of analysis. It is the intention of this final article in the series on managerial power to develop the general model of managerial power to include the organization compensation system. It is important to do this since compensation is probably the area in which management has its greatest opportunity of exercising power.

If ever there is a topic that raises controversy it is surely compensation - and in particular pay. There has been an on-going argument between those who consider compensation to be very important, and those who consider it as hardly worth mentioning as part of a 'respectable' motivation theory. Thus, for example, Herzberg, ${ }^{3}$ has argued that compensation is part of the 'hygiene factors' which constitute only the non-motivational context of work and not part of the 'motivators' that truly influence performance on the job. Yet if Lawler's $s^{4}$ work, and later work on Herzberg ${ }^{5}$ is considered and the news media taken note of, it appears as if pay is extremely important - indeed that it could well be considered as the primary motivational force in organizations.

It is clearly crucial to organizational effectiveness that the pay controversy be resolved by examining the extent to which management is able to exert power through the compensation system, yet the two concepts of managerial power and compensation have not traditionally been considered together. It is the task of this article to attempt the integration of these two areas through the presentation of a contingency model of compensation as a source of managerial power.

\section{The nature of compensation}

It was noted in the earlier articles in this series ${ }^{1,2}$ that power is a difficult concept to define because of a number of emotional and methodological problems. In a way there is the opposite problem regarding the definition of compensation - it is thought to be so easy to define that relatively few writers have bothered to do so.

Thus despite the voluminous literature on the topic it is surprising to find that a definition of compensation is given in only a very few instances. ${ }^{6}$ It is presumably assumed that the meaning of compensation is obvious probably no more than money and fringe benefits. It is important that compensation be defined in far broader terms, and so it is suggested that organizational compen- 
sation is everything that management consciously gives to the employee in return for his position in and contribution to the organization.?

This definition emphasizes the tangibles of the reward system as consciously manipulated by management, but includes far more than just the pay and fringe benefit component. According to Belcher ${ }^{8}$ the compensation system can be considered to include economic performance rewards, economic membership rewards, and nonfinancial rewards. Economic performance rewards are given for increased productivity and are typically in the form of incentive payment systems. Economic membership rewards are not dependent on performance in the organization, but simply upon belonging to the company. Typically an employee's basic salary, while often determined according to organizational contribution, since little distinction in basic salary is made between good and bad performers, is a memberhip reward. Much of the real power of the compensation system is to be found in the non-financial rewards management are able to offer employees. The type of supervisor an employer has, the climate of his work group and the meaningfulness of his job are some examples of non-financial rewards.

Since the pay system offers more than just economic rewards it should be clear that the manager making use of compensation power has at his disposal a source of influence which comes from more than just the 'reward power base' of managerial power. As a result of its wide symbolic value compensation power is broad-based in its impact on organizational performance.

Although it has been suggested that compensation is important it has to be admitted that its theoretical status is still rather low. It remains an area of prescriptive rather than theoretical contributions in which there is a large 'application gap' between theory and practice. Most of the prescriptive work gives management practical ideas as to the improvement of their organizational compensation system which are based in an informal way upon previous experience, rather than upon research-based theory. Perhaps the most significant theoretical contribution has been made by Lawler, particularly in his 1971 text. $^{4}$ Lawler has developed comprehensive theoretical models of the importance of pay and its role as a motivator of employee performance.

\section{Compensation as a Source of Power}

The reward system is an inseparable part of the overall management power structure in an organization. This is because the nature of the power structure determines the way resources are allocated through the reward system. Thus while the power structure indicates the balance of managerial influence in an organization, it is primarily through the reward system that this influence is expressed in the form of managerial control. As Katz and $\mathrm{Kahn}^{9}$ note, the resource allocation of an organization generally favours the power holders in that organization.

It is suggested that compensation is a source of managerial power at two levels: at a specific level by way of incentives to particular types of employee behaviour; and at a general level as an expression of broad managerial intent or strategy. At the specific level compensation can serve to promote higher productivity - the objective emphasized in Lawler's ${ }^{4}$ work, or to ensure organizational maintenance - the objective emphasized in Meyer's ${ }^{10}$ propositions. At the more general level compensation has the power to support the basic management philosophy of an organization. Employees tend to carry out those behaviours rewarded by the compensation system, and so, if the reward system is congruent with the authority system in the organization, management will have considerable power available to ensure that employees conform to the given structure. This is very much the emphasis of the considerable work done by Lupton and his associates" in attempting to design reward systems appropriate to organization characteristics. If the managerial power of a compensation system is a function of its congruency within organizational context then the most adequate representation of its operation will be provided by a contingency model.

\section{The proposed model of compensation power}

The proposed model of compensation power builds on the model of managerial power presented in the first article in this series by including in the model some of Lawler's theoretical conceptions. ${ }^{4}$ It is really only in the 'Expectancy' model of motivation as adapted by Lawler ${ }^{4}$ that an adequate representation of the power of compensation is provided.

Given the relatively broad conception of compensation proposed earlier it is suggested that compensation as a source of power should be very much a part of the model at both the macro and micro-levels. For, while the primary focus of organizational compensation is as a source of power in the hands of the individual manager at the level of his relationship with individual employees, the basic structure and policy framework within which the compensation system operates is set at the macrolevel of managerial power. Thus it is proposed that a model of compensation power can be placed in the same framework as the model of managerial power. The model of compensation power is presented in Fig. 1.

At the macro-level compensation power is again conceived of as taking place in terms of a particular organizational compensation structure, which in turn is embedded in an overall environment. This environment not only affects the compensation structure but also sets the basic management philosophy and employee values which act together in influencing the micro-level of the model - the compensation relationship between manager and subordinate. The primary modification made on the basic power model is at the micro-level of analysis. It is still suggested that the essence of the power relationship between manager and subordinate is in terms of a psychological contract between them, but it is felt necessary to spell out in more detail exactly how compensation operates in motivating employees. Thus at the micro-level a model of compensation power is presented in terms of the Expectancy Theory of motivation as proposed by Lawler. ${ }^{4}$

In terms of the Expectancy model it is argued that the power of the reward system is dependent upon three factors: The perceived value of the rewards offered to the employee; The employee's subjective perception of the probability that effort leads to performance; The employee's subjective perception of the probability that performance leads to a valued reward. Satisfaction is 
ENVIRONMENTAL VARIABLES

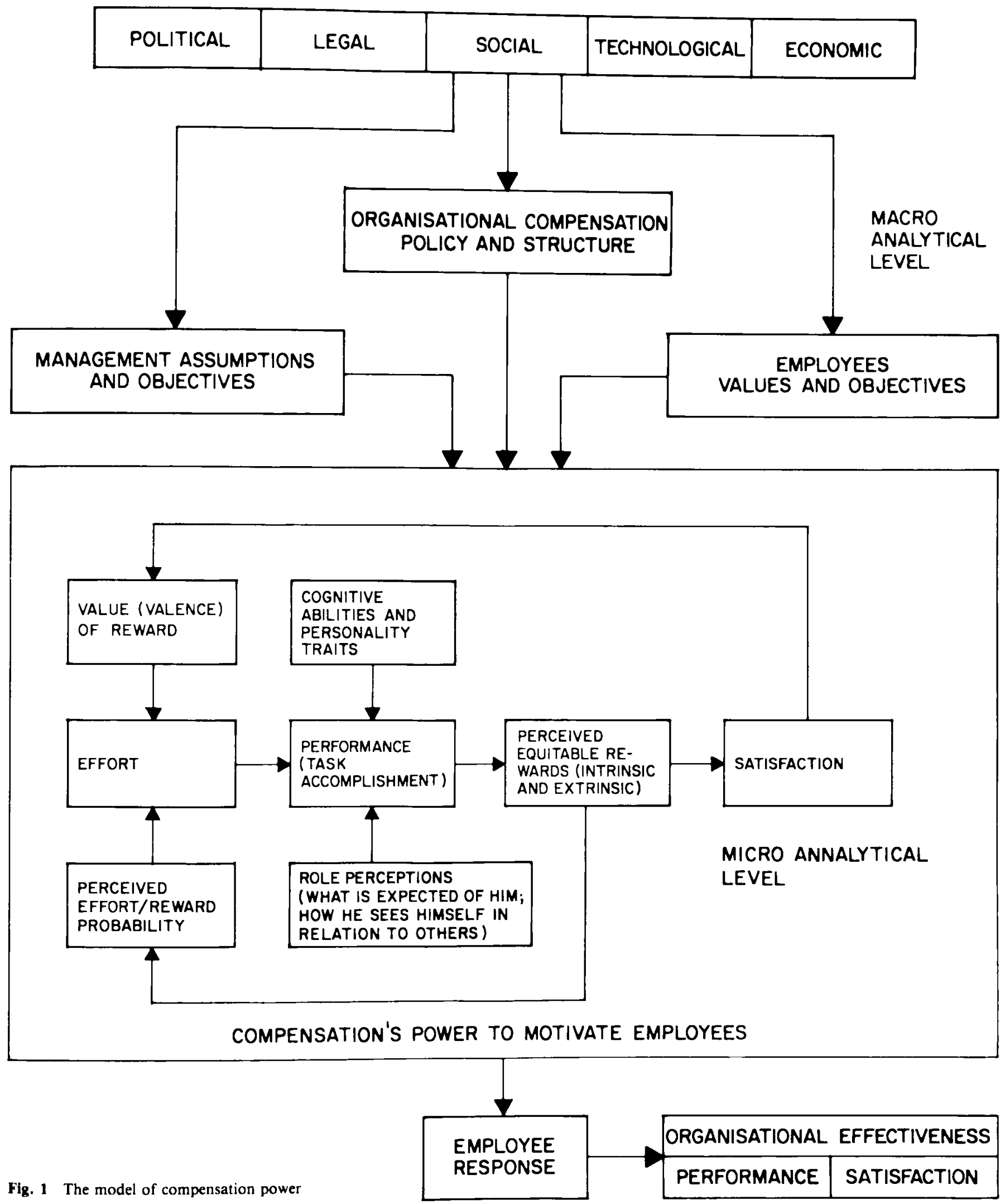

considered to be a result of and not a cause of effective performance. Thus satisfaction is not an end in itself but rather the result of a performance based system in which valued rewards follow upon desired performance.

Some indication of how the compensation element of this model might be used in practice to determine compensation policy is provided in the work of both Lawler ${ }^{4}$ and Orpen ${ }^{12}$. Orpen's work is particularly useful because of its application to Black employees in South Africa.

In considering a contingency model of compensation power what is required is a framework which links managerial power with decisions made about goal or work behaviour, within the context of the constraints and opportunities inside and outside the organization. In essence, it must be a model that embraces the individual, the organization and the environment. It is suggested that the 
model presented here fulfills these conditions. Before it is possible to conclude this article, however, it is useful to present some discussion on the utility of the model in terms of the type of criteria suggested previously by the author. ${ }^{1}$

\section{Evaluating the model}

Three evaluation criteria of a model were particularly highlighted: That it facilitate understanding, that it match with the complexity of the area, and that it have predictive validity. A brief consideration is given to each of these in turn.

The first requirement, namely the facilitation of understanding is really something of a subjective judgement and is to some extent subsumed by the other requirements. In so far as the model appears to have enabled the understanding of the complex interrelationships which constitute compensation in organizational context, and yet has not over-simplified managerial power, this requirement has been met.

In terms of the second requirement it is felt that the model accords with complex reality. It takes both structural and process variables into account in considering compensation power in terms of a relationship taking place within an environmental and organizational setting. The model clearly offers the opportunity for meaningful contingency analyses of compensation. At the interpersonal level in particular, account is taken of the large number of contingency variables that come into play in the relationship between pay motivation and satisfaction, such as ability, personality, self-perception, role perception and work group values.

It is the third requirement of predictive validity which is probably the most important to a managerial power model. It is essential that the model be able to predict differences between employees in their response to managerial power, and predict conditions for organizational effectiveness and so suggest practical implications which lead to managerial action. It should be noted, of course, that from the model it would not be expected that there be linear relationships between compensation and behaviour. The key to compensation power is in the manager's manipulation of the pay system, but the effect of context variables may well be to alter predicted relationships. Nonetheless there does appear to be general support for Lawler's ${ }^{4}$ conception of compensation power upon which the interpersonal level of the model is based. ${ }^{13}$ Evidence appears to be clearer, however, for the Expectancy theory predictions regarding performance, than for the prediction that satisfaction will follow only upon performance related pay. Thus, for example, in an extensive review carried out by Schwab and Wallace ${ }^{14}$ it was found that only actual pay level consistently predicted pay satisfaction. In that the model does include the Equity theory requirement for satisfaction of 'perceived equitable rewards', it does allow for this finding.

A useful aspect of the model is its contingency emphasis which provides a basis for the distinction between various possible antecedants of individual differences in response to managerial power.

The model distinguishes societal and organizational variables, structural and personal variables, process and outcome variables and so makes comparative difference prediction a possibility. Thus the model would predict, for example, that if one group of employees is faced with a different structural pattern of power from another group, they would certainly show a different behavioural response to managerial power than the other group.

\section{Conclusion: Managerial implications of the model}

The model of compensation power presented has provided a basis for widening the scope of compensation research beyond a narrow focus on financial rewards by presenting the reward system as very much a part of the organization-wide power and authority structure. It is hoped that this may lead to a method of building upon differing findings which can be integrated within a single contingency model.

In addition, however, it is also considered that the model does result in practical implications for managerial action. At the risk of over-simplification it is suggested that there are two major implications of the model:

- There is a need for an open-systems or contingency model of compensation power of fering a sufficiently broad conception which makes clear that desired employee behaviours follow from a complex interrelation of compensation, organizational characteristics, managerial assumptions and employee values.

- The immediate manager plays a key role through his relationship with his subordinate in setting up compensation systems that are genuinely a source of managerial power.

The two implications are closely related to one another in that management cannot go about increasing the power of compensation without seeing it as part of a total system. Thus management will exercise compensation power to the extent that they are able to offer what employees are seeking, and to the extent that the overall environment is such that the perceived negative consequences of carrying out management's wishes are minimized.

A point which Lawler has been making for almost a decade $^{15}$ is that compensation is sufficiently powerful to be used directly to change organizations in the direction of achieving genuine organizational effectiveness. It is generally assumed that the compensation system must be structured so as to fit the climate of the organization, however it makes equal sense to argue that the organization should change to fit the nature of the compensation system. The strategic role of compensation in organisational change is supported by the broad-based viewpoint of the model, emphasizing as it does the close link between compensation and organization variables.

If understood and effectively utilized, compensation is a source of considerable managerial power. It is considered that the contingency model presented in this paper provides the basis for this understanding and utilization.

\section{References}

1. TEMPLER, A.J. A model of managerial power in the organization. S. Afr. J. Bus. Mgmt., 10, 1979, pp. $107-111$.

2. TEMPLER, A.J. A micro-model of managerial power. $S$. $A f r . J$. Bus. Mgmt., 11, 1980, pp. 75-78.

3. HERZBERG, F. et al. The Motivation to Work. John Wiley, New York, 1959. 
4. Lawler has written a great deal on the topic of compensation, but his most significant text is: LAWLER, E.E. Pay and Organisational Effectiveness: A Psychological View. McGraw-Hill, New York, 1971.

5. BACKER, W. ' $n$ Kritiese evaluering van die motiveringshigieneteorie van Hertzberg. Unpublished D. Litt. et Phil. dissertation, University of South Africa, Pretoria, 1978.

6. NASH, A.N. \& CARROLL, S.J. The Management of Compensation. Monterey, Brooks/Cole Publishing Co., California, 1975, p. 3.

7. This definition can be seen to draw upon that of NASH and CARROLL, op cit, p. 3.

8. BELCHER, D.W. Compensation Administration. Englewood Cliffs, New Jersey: Prentice-Hall, 1974. pp. 3-16.

9. KATZ, D. \& KAHN, R.L. The Social Psychology of Organisations. John Wiley. New York, 1966, pp. 30-200.

10. MEYER, H.H. The Pay for Performance Dilemma. Organ. Dyn., Winter 1975 , pp. $39-50$.
11. See for example in: LUPTON, T. \& BOWEY, A.M. Wages and Salaries, Middlesex: Penguin Books, 1974; and LUPTON, T. \& GOWLER, D. Selecting a Wage Payment System. Kogan Page. London, 1969.

12. ORPEN, C. Productivity and Black Workers in South Africa. Juta \& Co., Cape Town, 1976.

13. For example: FOSSUM, J.A. An Examination of the Effects of Pay Expectancy and Individual Differences on the Perception of Inequity. Unpublished $\mathrm{Ph}$. D. Dissertation: Michigan State University, 1975; GILES, B.A. \& BARRETT, G.V. Utility of Merit Increases. J. Appl. Psychol., 55, 1971, pp. 103-109; KLEIN, S.M. Pay Factors as Predictors of Satisfaction. Acad. Mgmt. J., 16, 1973, pp. 598-611.

14. SCHWAB, D.P. \& WALLACE, M.J. Correlates of Employee Satisfaction with Pay. Ind. Rel., 13, 1974, pp. 78-89.

15. This point has been made in both 1971: LAWLER, E.E. op cit, and in 1978: LAWLER, E.E. \& BULLOCK, R.J. Pay and Organisational Change. Personn. Admin., 23, 1978, pp. 32-36. 